Trinity University

Digital Commons @ Trinity

Political Science Faculty Research

Political Science Department

$4-2000$

\title{
American Indians in Court: The Burger and Rehnquist Years
}

John R. Hermann

Trinity University, jhermann@trinity.edu

Follow this and additional works at: https://digitalcommons.trinity.edu/polysci_faculty

Part of the Political Science Commons

\section{Repository Citation}

Hermann, J.R. (2000). American Indians in court: The burger and Rehnquist years. Social Science Journal, 37(2), 245-259. doi: 10.1016/S0362-3319(00)00058-6

This Article is brought to you for free and open access by the Political Science Department at Digital Commons @ Trinity. It has been accepted for inclusion in Political Science Faculty Research by an authorized administrator of Digital Commons @ Trinity. For more information, please contact jcostanz@trinity.edu. 


\title{
American Indians in Court: The Burger and Rehnquist Years
}

\author{
JOHN R. HERMANN \\ Trinity University
}

\begin{abstract}
The Supreme Court and individual justices' treatment of American Indian interests has generated relatively little scholarly attention. To fill this vold in the extant literature, this study seeks to examine how American Indian interests fared before the Supreme Court of the United States during the Burger and Rehnquist Courts (1969-1992 October terms) and attempts to discern the factors influencing their treatment. The findings indicate that while American Indian interests won $48 \%$ of their cases, the Burger Court was much more sympathetic than the Rehnquist Court to the plight of this politically dicadvantaged group. The error correcting strategy, the ideological proclivities of the justices, and the issue area heing litigated were all influential explanatory variables. Interestingly, the Solicitor General's Office had an adverse influence when it opposed American Indian interests as a direct or thırd party, hut had little impact when supporting their interests.
\end{abstract}

Like many other disadvantaged groups, American Indians have also turned to the courts when they lack access or clout in the electoral process (Cortner, 1968; Lawrence, 1990; O'Connor, 1980; O'Connor and Epstein, 1982, 1983; Vose, 1959). Unlike many other disadvantaged groups, the litigation activities of American Indians have not garnered much scholarly attention (but see, Deloria and Lytle, 1983; Shattuck and Norgren, 1979, 1991; Wilkins, 1990). ${ }^{1}$

Given that so few scholars have offered a systematic treatment of American Indians in the American legal system, this study offers an examination of how American Indians fared in the Burger and Rehnquist Courts (1969-1992 terms) and attempts to discern the

*Dırect all correspondences to. John R Hermann, Department of Polıtıcal Science, Trinity Unıversity, 715 Stadıum Drive, San Antonıo, TX 78212.

The Social Science Journal, Volume 37, Number 2, pages 245-259.

Copyright $(1) 2000$ by Elsevier Science Inc.

All rights of reproduction in any form reserved. ISSN: 0362-3319. 
factors that contributed to their success. More specifically, this study asks five questions: (1) How successful are American Indians in the Supreme Court? (2) Do American Indians fare better when they are the appellant? (3) What type of American Indian issues dominate the Court's agenda? (4) Does the Court's support for American Indians vary based on the issue present? (5) What impact does the presence of the Solicitor General as a party and an amicus have on American Indian cases?

In addition to the apparent void in the literature, there are at least three reasons that American Indians' treatment by the Burger and Rehnquist Courts merit attention. First, at least two justices from the Burger Court have placed great importance on American Indian cases. Said one justice:

\begin{abstract}
We now have three westerners on the Court and we are very concerned about. . Indian cases. And you can tell by our votes for cert. that we are interested in them (Perry, 1991, p. 261).
\end{abstract}

Another justice stated:

Actually, I think the Indian cases are kind of fascinating. It goes into history and you learn about it, and the way we abused some of the Indians, we that is the U.S. government (Perry, 1991, p. 262).

Second, American Indian cases have received more attention from the Burger and the Rehnquist Courts. The Supreme Court decided more American Indian cases (35) in the 1970s than in any other previous decade in the Court's history (Wilkinson, 1987, p. 2). The 1980s saw even more as the Supreme Court decided more than 40 cases involving Indian issues.

And, third, given that American Indian activities are regulated primarily by the federal government (and not the states), the U.S. Supreme Court plays an especially important role in the policy formation of Indian rights. Since the Marshall Court's decision in Worcester v. Georgia (1832), the Court has consistently held that "matters affecting Indians in Indian country are thus as a general rule excepted from the usual application of state law..." (Cohen, 1982, p. 260).

\title{
LITERATURE AND HYPOTHESES
}

To understand how American Indians fared in the Supreme Court during the 1969-1992 terms, we examine two factors that could influence the Court's and the justices' decisionmaking: (1) the "error correcting strategy"; and (2) the office of the Solicitor General as a direct and third party.

\section{The Error Correcting Strategy}

The U.S. Supreme Court's propensity to support the appellant, called the "error correcting strategy," is well chronicled (Baum, 1976, 1977, 1979; Epstein and O'Connor, 1988; George and Epstein, 1992; Salokar, 1992; Songer, 1979; Sheehan et al., 1992; Wasby, 1993). Many argue that the justices take cases when they "seek to 'correct errors' 
in the lower courts by voting to grant a hearing whenever a lower-court decision departed significantly from their most preferred doctrinal position" (Baum, 1977, p. 14). We expect that American Indian interests will also benefit from their status as appellants. More precisely, we expect American Indian claimants to win more often when they are the appellant. Conversely, their success rates should be noticeably lower when they are the respondent.

\section{The Solicitor General}

Lawyers from the office of the U.S. Solicitor General are the most frequent litigators before the Court and enjoy phenomenally high success rates there regardless of whether they represent litigants as direct or third parties (Caplan, 1987; O'Connor, 1983; Puro, 1971; Salokar, 1992; Scigliano, 1971; Segal, 1984, 1988, 1990; Segal and Reedy, 1988). Several reasons have been offered to explain the Solicitor General's success. First, as Galanter (1974) notes, the federal government is a special kind of repeat player. The office has advanced intelligence, a small attrition rate, and unparalleled expertise. Second, unlike other parties, the Solicitor General's office is not constrained by the financial burdens of litigation. The office does not concern itself with start-up costs and it can continue the litigation process regardless of financial expenses. Third, the Solicitor General generally enjoys an excellent reputation with the Court, as the office is well respected for the quality of briefs filed and the presentation of its oral arguments (McGuire, 1993).

Perhaps the most important reason for the Solicitor General's success before the Court results from the special relationship between the executive and judicial branches. Scigliano (1971) argues that it was the Framer's intentions to create a harmonic relationship between the Court and the president to offset the most powerful branch, Congress. He contends that there is strong evidence for this perspective: There is a natural affinity between the powers of the executive and judicial branches; and, as presidential appointees, the justices often represent the prerogatives of the executive.

Given these reasons, the Solicitor General's unparalleled success when representing the federal government before the Court is of little surprise. Scigliano's (1971) sample of cases found that the Solicitor General's office won over $60 \%$ of its cases during the nineteenth and twentieth centuries. Additionally, Segal (1984) showed that the Supreme Court was more likely to uphold federal searches defended by the federal government than searches conducted and defended by state officials. Still, in a more recent study of the 1959-1986 Supreme Court terms, Salokar (1992) finds that the Solicitor General's success rates as a direct party was approximately $70 \%$.

Interestingly, "the [federal] government has an even better record as amicus curiae than as a direct party in litigation" (Scigliano, 1971, p. 179). Scigliano (1971) finds that the Solicitor General's success rates as amicus in the post 1945 era were more than $85 \%$. Puro (1971) also finds that Solicitor General was on the winning side approxımately $75 \%$ of the time as a third party between 1920-1968. In examining sex discrimination cases before the Supreme Court from 1971-1984, Segal and Reedy (1988, p. 563) conclude that "the position taken by the solicitor general is clearly related to the decisions of the Court." And, in a subsequent study, Salokar (1992) shows that the Solicitor General won more than $70 \%$ of the time as an amicus between 1959-1986.

The literature suggests that the success of American Indian claimants before the Supreme Court should also be influenced by the presence of the Solicitor General. When 
the Solicitor General supports American Indian claimants as a direct or third party, their success rates should be higher than when there is no such support. In sharp contrast, American Indians' success rates should be impaired when the Solicitor General is a direct or third party in opposition.

As a representative of direct and third parties, the Solicitor General should also be an especially active player in American Indian cases because the federal government has a fiduciary responsibility to American Indians. More specifically, what is called the trust relationship of the United States with American Indians "arises out of the constitutional plan to delegate plenary authority over American Indian affairs to the federal government and the duties of protection undertaken by treaty and federal statute" (Cohen, 1982, p. 651). ${ }^{2}$ Thus, in many American Indian cases, the federal government acts as a trustee as a direct or third party in protecting American Indian rights. In others, American Indians sue the federal government for alleged breaches in fulfilling its trust responsibility.

\section{METHODS}

The 82 full opinion cases regarding American Indians decided by the U.S. Supreme Court during its 1969-1992 terms were identified by examining the United States Reports (see Appendix A). ${ }^{3}$ Each case was coded as decided by the Court as for or against American Indians or their interests. Seven cases were excluded from analysis because they were split decisions; that is, the Court affirmed and reversed on the central issue(s) in the case, leaving a population of 75 cases. To determine whether the Solicitor General participated and the nature of that participation, the United States Supreme Court's Records and Briefs on microfiche were examined for each case.

American Indian cases are defined as those that concerned or involved American Indians or tribal affairs. Success rates were computed by dividing the number of cases in which the Court supported American Indian claims by the total population of cases. Theoretically, these scores can range from 0 to 1 . The same calculations were made for each justice to calculate individual support rates.

\section{FINDINGS}

As revealed in Table 1, American Indians collectively won $48.0 \%$ of the 75 cases decided by the Supreme Court during the 1969-1992 terms. The Burger Court (53\%) was much more supportive of American Indian cases than the Rehnquist Court (31\%). This may be attributed to President Reagan's and Bush's conscious efforts to appoint justices who echoed their conservative agendas (Schwartz, 1993, pp. 372-375; Segal and Spaeth, 1993, pp. 244-245). The Rehnquist Court's conservative philosophy clearly had a detrimental affect upon the success of American Indian claimants during the 1986-1992 terms.

The individual support rates for American Indians evidenced by the Reagan and Bush appointees bolster this contention. Justices O'Connor, Rehnquist (elevated to Chief Justice), Scalia, Kennedy, Souter, and Thomas all supported American Indians less than $50 \%$ of the time. Justice Scalia's voting record, for example, shows that "his initial ventures into the world of Indian law were extremely hostile toward Native American legal positions" (Wunder, 1994, p. 180). Justice Rehnquist's low support for American 
Table 1. Courts' and Justices' Support for American Indian Case: 1969-1992

\begin{tabular}{lccc}
\hline \multicolumn{1}{c}{ fustrces \& Court } & $\begin{array}{c}\text { Support Rates } \\
(\mathrm{N})\end{array}$ & $\begin{array}{c}\text { Support Rates } \\
\text { as Appellant } \\
(\mathrm{N})\end{array}$ & $\begin{array}{c}\text { Support Rates } \\
\text { as Respondent } \\
(\mathrm{N})\end{array}$ \\
\hline Burger and Rehnquist Courts & $48.0 \%(75)$ & $719 \%(32)^{* * *}$ & $30.2 \%(43)^{* * *}$ \\
Burger Court & $52.5(59)$ & $75.0(28)^{* * *}$ & $32.2(31)^{* * *}$ \\
Rehnquist Court & $31.3(16)$ & $50.0(4)$ & $25.0(12)$ \\
Douglas & $93.8(16)$ & $100.0(13)^{* *}$ & $66.7(3)^{* *}$ \\
Marshall & $75.7(70)$ & $90.3(31)^{* * *}$ & $64.1(39)^{* * *}$ \\
Brennan & $73.5(68)$ & $89.7(29)^{* * *}$ & $61.5(39)^{* * *}$ \\
Blackmun & $62.5(72)$ & $689(29)$ & $58.1(43)$ \\
Stewart & $55.3(38)$ & $654(26)^{* *}$ & $33.3(12)^{* *}$ \\
Burger & $50.0(58)$ & $75.0(28)^{* * *}$ & $267(30)^{* * *}$ \\
Harlan & $50.0(2)$ & $1000(1)$ & $0.0(1)$ \\
Powell & $44.6(56)$ & $68.0(25)^{* * *}$ & $25.8(31)^{* * *}$ \\
White & $42.7(75)$ & $59.4(32)^{* * *}$ & $30.2(43)^{* * *}$ \\
Souter & $40.0(5)$ & $0.0(1)$ & $50.0(4)$ \\
O'Connor & $36.1(36)$ & $667(6)^{* *}$ & $30.0(30)^{* *}$ \\
Stevens & $328(58)$ & $33.3(18)$ & $32.5(40)$ \\
Rehnquist & $29.6(71)$ & $48.3(29)^{* * *}$ & $16.7(42)^{* * *}$ \\
Scalıa & $25.0(16)$ & $50.0(4)^{*}$ & $16.7(12)^{*}$ \\
Thomas & $250(4)$ & $0.0(1)$ & $33.3(3)$ \\
Kennedy & $10.0(10)$ & $00(3)$ & $14.3(7)$ \\
Black & $0.0(3)$ & $0.0(2)$ & $0.0(1)$ \\
\hline N & & &
\end{tabular}

N. Number of cases

For the support rates of American Indian claımants as the appellant and respondent. a Pearson's (hi-square test (one-taıled) was emploved ${ }^{*} \mathrm{p}<\bullet \bullet 1,{ }^{* *} \mathrm{p}<005,{ }^{* * *} \mathrm{p}<001$

Indian claims was consistent with his generally low support rates for disadvantaged groups. In fact, he was more supportive of American Indian claims (30\%) than for gender-based claims (16\%) (O'Connor and Epstein, 1983, p. 328). Justice Kennedy's conservative jurisprudence toward civil liberties and civil rights claimants, moreover, carries over to American Indians (10\%) (Segal and Spaeth, 1994, p. 254). And, Justice O'Connor's support rates for American Indian claimants are analogous with her support for most other minority groups (Segal and Spaeth. 1994, p. 254).

On the other end of the ideological spectrum, Justices Douglas, Marshall, Brennan, Blackmun, and Stewart supported American Indian claimants in over 50\% of the cases. In the case of Justice Douglas, his liberal tendencies have been well-documented (Rohde and Spaeth, 1976, p. 143; Segal and Spaeth, 1993, pp. 252-253). And, his love of the land and his support for American Indian interests are well-known (Johnson, 1990, pp. 191-197; Wilkinson, 1990, pp. 233-245). Johnson (1990, p. 206) for example, notes that Justice Douglas was "an ardent supporter of tribal self-determination and a firm believer that agreements with Indian tribes should be construed in favor of the Indians, and should be upheld." More interesting, is the uncharacteristic low support for American Indian interests by the usually more liberal Justice Stevens (33\% in 58 cases). For example, O'Connor and Epstein (1983, p. 328) found Justice Stevens supported gender-based claims $57 \%$ of the time. Other studies have found him to be among the most liberal on the Court (Heck, 1981, p. 197: Goldman, 1982, p. 542). 
Curiously, Justice Burger's support rates were much higher for American Indian claimants than for African Americans or claims involving gender. Burger supported American Indian claims in 58\% of the 19 cases during the 1972-1976 terms, whereas he supported African American litigants in only $34 \%$ of the 65 cases examined by Ulmer and Thomson during the same period (1981, p. 449). Similarly, Burger s support for American Indian claims were much higher ( $51 \%$ in 39 cases) than for gender-based claims ( $25 \%$ in 68 cases) for the 1969-1981 terms (O'Connor and Epstein, 1983, p. 328).

Most of the other justices who served during 1969-1992 terms had similar support rates for American Indian claimants in relation to other politically disadvantaged groups (Heck, 1981; O'Connor and Epstein, 1983; Segal and Spaeth, 1993). In sum, considerable variation exists among the individual justices' support rates for American Indian claims and the variation appears to be largely a function of the ideological predispositions of the justices.

\section{Support Scores as an Appellant}

American Indian interests clearly benefited from appellant status. As indicated in Table 1, the Court supported American Indians as the appellant in more than $70 \%$ of the cases decided during the 1969-1992 terms (and the relationship is significant at the 0.01 level). The Burger Court was also more supportive of American Indians as the appellant; being the appellant, however, had only a moderate influence on the Rehnquist Court's decisions. In sharp contrast, the Court's support (1969-1992 terms) for American Indians as the respondent plummets to less than a third.

The individual justices were also more supportive of American Indians as the appellant. ${ }^{4}$ With the exceptions of Justices Rehnquist and Stevens, every justice supported American Indians as an appellant in more than $50 \%$ of the cases (and the relationship is significant for 9 of the 11 justices). Further, when we controlled for American Indian claimants as the appellant, the low support rates by Justice O'Connor possibly may be explained. In the 36 cases in which O'Connor participated, American Indians were the appellant in only $17 \%$. O'Connor's support rates may have been higher if American Indians were the appellant in a greater number of cases. Conversely, with the exception of Justice Stevens, all of the justices support rates sharply declined when American Indians were the respondent.

\section{Issue Areas}

Table 2 reveals the kinds and distribution of issue areas in which American Indian cases fall. Four issues-land claims, natural resources, taxation, and what is termed here as procedure/jurisdiction, which are cases that involve questions peculiar to tribal claims or the status of reservations-make-up just under $90 \%$ of the cases decided by the Burger and Rehnquist Courts. The types of cases decided by the Court involving American Indians are strikingly different than those involving African Americans and women. Unlike those of other politically disadvantaged groups, American Indian cases did not primarily involve traditional civil rights and liberties issues, at least during the 1969-1992 terms. As a politically disadvantaged group, American Indian interests are more unique and diverse in relation to their counterparts. 
Table 2. Court's Support Rates for Different American Indian Issues: 1969-1992

\begin{tabular}{lrcc}
\hline \multicolumn{1}{c}{ Issue Area } & $\mathrm{N}$ & Distribution of Issues $(\%)$ & Support Rates (\%) \\
\hline Procedure/lurisdiction & 27 & 29.3 & 500 \\
Land Claıms & 17 & 22.7 & 52.9 \\
Natural Resources & 15 & 20.0 & 33.3 \\
Tax & 12 & 160 & 75.0 \\
Civil Rights/Civil Liberties & 6 & 80 & 33.3 \\
Other & 2 & 27 & 0.0 \\
Criminal & 1 & 1.3 & 100.0 \\
Total & 75 & 100.0 & \\
\hline
\end{tabular}

\section{Support Rates Based on Issue}

As Table 2 suggests, the success rates of American Indian claimants varied considerably based on the issue area being litigated. Given that the literature does not offer many expectations regarding the relationship between the issue area being litigated and their corresponding success rates, these findings are more exploratory.

In the procedure/jurisdiction arena, for example, American Indians won 50\% of the 22 cases. The outcome of these decisions is usually determined by whether the federal or state governments are trying to assume authority over American Indian affairs. American Indians usually win when states are involved and lose when the federal government is a party to the dispute. For example, in Cabazon Band of Mission Indians v. California (1987), Justice White, writing for the majority, held that California could not regulate gambling on the Cabazon reservation. However, in Rhoades v. Vigil (1992), the Court held that the Indian Health Department of the United States could unilaterally abrogate a health program for handicapped Indian children.

In land claim cases, American Indians enjoyed a 53\% $(n=17)$ success rate. One of the most important victories for American Indians in this area was in County of Oneida v. Oneida Indian Nation (1985). At issue was the validity of an agreement in 1795 between the Oneida Indian Nation and New York regarding the transfer of land to the state (because the transfer did not have the required prior federal approval pursuant to the Trade and Intercourse Act of 1790). In a 5 to 4 decision, the Court upheld the 175-year-old agreement as invalid, which allowed the Oneida Indian nation a federal common law right to sue for breach of its possessory rights to aboriginal lands.

In the area of natural resources, American Indians were not as successful as in land claims or procedure/jurisdiction issues. They won only a third of these cases. The low success rates in the natural resource cases may be attributed to the Court's tendency to defer to the state's and Congress's police powers to preserve scarce resources in spite of the fact that resources are also critical to the survival of tribes, as tribes. In United States v. Dion (1986), for example, the Court held that, pursuant to the Eagle Protection Act, American Indians were prohibited from hunting eagles.

By contrast. American Indians enjoyed a very high success rate in taxation cases, $75 \%$ $(n=12)$. Most of these cases involved attempts by states to tax individuals who resided in Indian country. This high success rate may be due to a long line of precedent established by the Court as well as by the codification of these principles in the Indian Civil Rights Act of 1968. The Indian Civil Rights Act of 1968 prohibits state jurisdiction on tribal 
lands, unless consent is attained by Congress or the affected tribe. Further, since Worcester v. Georgia (1832), the Court has consistently held that states are, as a general rule, excluded from regulating tribal affairs. As the Court held in McClanahan v. Arizona State Tax Commission (1973), this principle also applies to state taxation. The Rehnquist Court, however, has started to chip away at this standard in Cotton Petroleum Corporation v. New Mexico (1989). In this case, the Court held that New Mexico could tax non-Indian oil producers on the reservation because the company's business involved non-Indian commerce.

\section{The Role of the Solicitor General}

One of the central expectations of this study was that the Solicitor General's office would be a particularly active participant in American Indian cases. This was the case. The Solicitor General's office either represented or filed an amici brief in $89 \%$ of the 75 cases decided by the Burger and Rehnquist Courts: The office supported American Indian interests in 41 of the 75 cases (54\%) and was the opponent in some form in 26 of the 75 cases $(35 \%)$. In contrast, Salokar (1992. p. 21), for example, finds that the Solicitor General participated in only " $48.5 \%$ of all cases decided on the merits by the Court from 1959-1989."

\section{Solicitor General in Support of American Indians}

Table 3 reveals the impact of the Solicitor General when representing and/or filing an amicus on behalf of American Indian interests. The Burger and Rehnquist Court's support rates are only moderately higher when the Solicitor General participates in any form. Although the Solicitor General as an amicus positively affected the overall success of American Indian claimants, the office's success as an amicus in American Indian cases is much lower than those found in other studies (Puro, 1971; Salokar, 1992; Segal, 1984, 1988, 1990). More interesting, however, is that the Solicitor General did not appear to have any influence on American Indian claimant's success as a direct party.

Although Segal (1988, pp. 138-139) concludes that the "solicitor general's ability to win ... is not dependent upon the type of issue being decided," Ivers and Parker (1993, p. 10) find that in religion cases prior to 1980 the Solicitor General "lost more cases than it won as an amicus litigant." Thus, the office's success may not only be dependent upon the issue being litigated, but the party it chooses to support. This is the central finding for the American Indian case.

The Solicitor General's influence (as a direct or third party on behalf of American Indian interests) on the individual justices' support rates varied. Justices Marshall, Brennan, Blackmun, Stewart, Souter, O'Connor, Stevens, Rehnquist, and Kennedy all were influenced by the Solicitor General's presence on behalf of American Indian interests, whereas Justices Douglas, Burger, Powell, White, Scalia, and Thomas were not. The Solicitor General's influence on the justices' voting behavior does not seem to be based on their ideological preferences. Both conservative and liberal justices alike were affected by the office's presence. This may indicate that the affect of the Solicitor General is justice specific. Thus, while the Solicitor General played an instrumental role in the decision-making calculus for some justices, different factors were more compelling for others. 
Table 3. Impact of the Solicitor General in Support of American Indian Cases: 1969-1992

\begin{tabular}{|c|c|c|c|c|}
\hline \multirow[b]{2}{*}{ Courts and Justices } & \multirow[b]{2}{*}{$\begin{array}{c}\text { Overall } \\
\text { Support Rates }\end{array}$} & \multicolumn{3}{|c|}{ Support Rates when the } \\
\hline & & $\begin{array}{c}\text { Solicitor General } \\
\text { as a Party' } \\
\text { Amicus on } \\
\text { behalf of } \\
\text { American Indian } \\
\text { Claimants (N) }\end{array}$ & $\begin{array}{l}\text { Solicitor General } \\
\text { as a Party on } \\
\text { behalt of } \\
\text { American Indian } \\
\text { Claimants (N) }\end{array}$ & $\begin{array}{l}\text { Solicitor General } \\
\text { as an Amicus } \\
\text { on behalf of } \\
\text { American Indian } \\
\text { Claimants }(\mathrm{N})\end{array}$ \\
\hline $\begin{array}{l}\text { Burger and Rehnquist } \\
\text { Courts }\end{array}$ & $480(75 \%)$ & $56.1(41)^{*}$ & $467(15)$ & $61.5(26)^{* *}$ \\
\hline Burger Court & $52.5(59)$ & $57.9(38)$ & $50.0(14)$ & $62.5(24)^{*}$ \\
\hline Rehnquist Court & $31.3(16)$ & $333(.3)$ & $0.0(1)$ & $50.0(2)$ \\
\hline Douglas & $93.8(16)$ & $87.5(8)$ & $75.0(4)$ & $100.0(4)$ \\
\hline Marshall & $75.7(70)$ & $84.2(38)^{* *}$ & $71.4(14)$ & $91.7(24)^{* * *}$ \\
\hline Brennan & $735(68)$ & $811(37)^{*}$ & $64.3(14)$ & $91.3(23)^{* * *}$ \\
\hline Blackmun & $62.5(75)$ & $70.0(40)^{*}$ & $66.7(15)$ & $72.0(25)$ \\
\hline Stewart & $55.3(38)$ & $60.0(25)$ & $72.7(11)^{*}$ & $50.0(14)$ \\
\hline Burger & $50.0(58)$ & $5.53(38)$ & $50.0(14)$ & $58.3(24)$ \\
\hline Powell & $44.6(56)$ & $47.2(36)$ & $462(13)$ & $47.8(23)$ \\
\hline White & $42.7(75)$ & $439(41)$ & $400(15)$ & $46.2(26)$ \\
\hline Souter & $40.0(5)$ & $100.0(2)^{* *}$ & NA. & $100.0(2)^{* *}$ \\
\hline O'Connor & $36.1(36)$ & $56.3(16)^{* * *}$ & $00(4)$ & $75.0(12)^{* * *}$ \\
\hline Stevens & $32.8(58)$ & $42.4(33)^{* *}$ & $63.7(11)^{* * *}$ & $31.8(22)$ \\
\hline Rehnquist & $296(71)$ & $36.6(41)^{*}$ & $467(15)^{* *}$ & $30.8(26)$ \\
\hline Scalia & $25.0(16)$ & $33.3(3)$ & $0.0(1)$ & $500(2)$ \\
\hline Thomas & $250(4)$ & 500121 & NA & $50.0(2)$ \\
\hline Kennedy & $10.0(10)$ & $33.3(3)^{*}$ & $0.0(1)$ & $50.0(2)^{* *}$ \\
\hline
\end{tabular}

N, Vumber of Case's

A Pearson's Chi-square test ione-tanled) was employed *p<0 $10,{ }^{* *} p<0.05,{ }^{* * *} p<001$

\section{The Solicitor General as an Opponent}

As Table 4 shows, the Solicitor General had a more profound affect when representing a direct party against American Indian interests than when representing a party on behalf of their claims. American Indians lost $68 \%$ (or won 32\%) of the 22 cases when the Solicitor General opposed them as a direct party during the 1969-1992 terms. For the Burger Court. American Indians lost $62 \%$ (or won 38\%) of their cases; and, during the more conservative Rehnquist Court, American Indians lost $83 \%$ (or won only $17 \%$ ). This finding garners more support for the contention that the Solicitor General's success may be constrained by the position the office takes. Given that the Solicitor General filed an amici brief against American Indians in only 4 of the 75 cases $(5 \%)$, it is difficult to reach any strong conclusions regarding the office's atypical affect on American Indian claimant's success before the Court.

Once again, the Solicitor General's impact as a direct party against American Indian interests on the individual justices' decisions varied. The Solicitor General's presence as a direct party was significant on the decisions of Justices Marshall, Brennan, Blackmun, Stewart, Powell, Souter, O'Connor, and Rehnquist. The central finding, once again, is that the office's affect on the justices" support rates crossed ideological camps, indicating that other forces in addition to the justices' attitudes were at work. 
Table 4. Impact of the Solicitor General as an Opponent in American Indian Cases: 1969-1992

\begin{tabular}{|c|c|c|c|c|}
\hline \multirow[b]{2}{*}{ Justıces \& Court } & \multirow[b]{2}{*}{$\begin{array}{c}\text { Overall } \\
\text { Support Rates }\end{array}$} & \multicolumn{3}{|c|}{ Support Rates when the. } \\
\hline & & $\begin{array}{c}\text { Solıcitor General as a } \\
\text { Party/Amicus Against } \\
\text { American Indian } \\
\text { Claimants (N) }\end{array}$ & $\begin{array}{l}\text { Solıcitor General } \\
\text { as a Party Against } \\
\text { American Indian } \\
\text { Claımants (N) }\end{array}$ & $\begin{array}{c}\text { Solıcitor General as } \\
\text { an Amicus Against } \\
\text { American Indian } \\
\text { Clamants }(\mathrm{N})\end{array}$ \\
\hline $\begin{array}{l}\text { Burger and Rehnquist } \\
\text { Courts }\end{array}$ & $48.0(75)$ & $34.6 \%(26)^{* *}$ & $31.8 \%(22)^{* *}$ & $50.0 \%(4)$ \\
\hline Burger Court & $52.5(59)$ & $38.8(18)^{* *}$ & $37.5(16)^{*}$ & $50.0(2)$ \\
\hline Rehnquist Court & $31.3(16)$ & $25.0(8)$ & $167(6)$ & $500(2)$ \\
\hline Douglas & $93.8(16)$ & $1000(7)$ & $100.0(6)$ & $100.0(1)$ \\
\hline Marshall & $75.7(70)$ & $54.2(24)^{* * *}$ & $47.6(21)^{* * *}$ & $100.0(3)$ \\
\hline Brennan & $73.5(68)$ & $56.5(23)^{* * *}$ & $50.0(20)^{* * *}$ & $100.0(3)$ \\
\hline Blackmun & $62.5(72)$ & $41.7(24)^{* * *}$ & $38.1(21)^{* * *}$ & $66.7(3)$ \\
\hline Stewart & $55.3(2)$ & $41.7(12)$ & $36.4(11)^{*}$ & $100.0(1)$ \\
\hline Burger & $50.0(58)$ & $353(17)^{*}$ & $40.0(15)$ & $0.0(2)^{*}$ \\
\hline Harlan & $50.0(2)$ & $500(2)$ & $50.0(2)$ & $\mathrm{NA}$ \\
\hline Powell & $44.6(56)$ & $29.4(17)^{*}$ & $25.0(16)^{* *}$ & $100.0(1)$ \\
\hline White & $42.7(75)$ & $38.5(26)$ & $40.9(22)$ & $25.0(4)$ \\
\hline Souter & $40.0(5)$ & $00(3)^{* *}$ & $00(2)^{*}$ & $0.0(1)$ \\
\hline O'Connor & $36.1(36)$ & $14.3(14)^{* *}$ & $09.1(11)^{* * *}$ & 33.3 (3) \\
\hline Stevens & $32.8(58)$ & $27.8(18)$ & $33.3(15)$ & $0.0(3)$ \\
\hline Rehnquist & $29.6(71)$ & $18.8(22)^{*}$ & $15.8(19)^{*}$ & $33.3(3)$ \\
\hline Scalıa & $25.0(16)$ & $25.0(8)$ & $16.7(6)$ & $50.0(2)$ \\
\hline Thomas & $25.0(16)$ & $00(2)$ & $00(1)$ & $0.0(1)$ \\
\hline Kennedy & $10.0(10)$ & $0.0(3)$ & $0.0(2)$ & $0.0(1)$ \\
\hline Black & $00(3)$ & $0.0(3)$ & $0.0(2)$ & $0.0(1)$ \\
\hline
\end{tabular}

N, Number of cases

A Pearson's chi-square test (one-talled) was employed ${ }^{*} p<010,{ }^{* *} p<005,{ }^{* * *} p<001$

\section{CONCLUSION}

Oppressed by majoritarian institutions, American Indians turned to the courts to lobby for their interests. Although the Burger Court's support for American Indian claims was slightly more than $50 \%$, Indians confronted a more antagonistic political environment during the Rehnquist Court. The conservative judicial appointees made by Presidents Reagan and Bush had a damaging affect on American Indian interests. Individual justices' support rates for American Indian claimants varied, however, ranging from 0 to $94 \%$. This variation appeared to be largely based on the ideological preferences of the justices.

In addition to the political preferences of the justices, the success of American Indians before Burger and Rehnquist Courts can be attributed to other factors. American Indian claimants clearly benefited from being the appellant. The justices and the Court employed the "error correcting" strategy, taking cases to correct "mistakes" below.

Additionally, the Court's support for American Indian claims depended upon the issue area litigated, with the Court being more supportive of tax cases and less supportive of natural resource claims. American Indian claimant's success in tax cases may be due to Congress producing clear guidelines in this area for the courts. It may be that in order for American Indians to fare better in other areas, Congress will need to give direction to the 
Court-especially in eras when conservatives dominate the Court and its decisionmaking.

The Solicitor General's influence as a direct or third party in American Indian cases depended upon the position it took in the case. Interestingly, the office's success was thwarted when it advanced American Indian interests, and the Solicitor General was more likely to win when Indian interests were opposed. Additionally, the Solicitor General's impact on the individual justices' behavior also varied and it was not a function of the justices' ideological preferences. Both conservative and liberal justices alike were affected by the Solicitor General's presence.

\section{APPENDIX A}

\section{TABLE OF CASES}

Cabazon Band of Mission Indians v. California, 480 U.S. 202 (1987)

Cherokee Nation v. State of Georgia, 30 U.S. (5 Pet.) 1 (1831)

Cotton Petroleum Company v. New Mexico, 490 U.S. 163 (1989)

County of Oneida v. Oneida Indian Nation, 470 U.S. 226 (1985)

Elk v. Wilkins, 112 U.S. 94 (1884)

Felix v. Patrick, 145 U.S. 317 (1892)

McClanahan v. Arizona State Tax Commission, 411 U.S. 164 (1973)

Rhoades v. Vigil. 113 S.Ct. 2025 (1992)

United States v. Dion, 476 U.S. 734 (1986)

United States v. Rickert, 188 U.S. 432 (1903)

Williarns v. Lee, 358 U.S. 217 (1959)

Worcester v. Georgia, 31 U.S. 515 (1832)

\section{American Indian Cases: 1969-1992 October Terms*}

Tonnipah v. Hickel, 397 U.S. 598 (1970).

Choctaw Nation v. Oklahoma, 397 U.S. 620 (1970).

Kennerly v. District Court, 400 U.S. 423 (1971).

United States v. Southern Ute Tribe, 402 U.S. 159 (1972).

Affiliated Ute Citizens vi. United States, 406 U.S. 128 (1972).

United States v. Jim, 409 U.S. 80 (1972).

Mescalero Apache Tribe v. Jones, 411 U.S. 145 (1973).

McClanahan v. Arizona State Tax Commission, 411 U.S. 164 (1973).

Keeble v. United States, 412 U.S. 205 (1973).

United States v. Mason, 412 U.S. 391 (1973).

Mattz v. Arnett, 412 U.S. 481 (1973).

Department of Game, Washington v. Puyallup Tribe, 414 U.S. 44 (1973).

Oneida Indian Nation v. City of Oneida, 414 U.S. 661 (1974).

Morton v. Ruiz, 415 U.S. 199 (1974).

Morton v. Mancari, 417 U.S. 535 (1974).

United States v. Mazurie, 419 U.S. 544 (1975).

Antoine v. Washington, 420 U.S. 194 (1975). 
Chemehuevi Tribe of Indians v. Federal Power Commission, 420 U.S. 395 (1975).

DeCouteau v. District County Court, 420 U.S. 425 (1975).

Fisher v. District Court, 424 U.S. 382 (1976).

Colorado River Water Conservation District v. United States, 424 U.S. 800 (1976).

Moe v. Confederated Salish \& Kootenai Tribes 425 U.S. 463 (1976).

Northern Cheyenne Tribe v. Hollowbreast, 425 U.S. 649 (1976).

Bryan v. Itsaca County, 426 U.S. 373 (1976).

Delaware Tribal Business v. Weeks, 430 U.S. 73 (1977).

Rosebud Sioux Tribe v. Kneip, 430 U.S. 584 (1977).

United States v. Antelope, 430 U.S. 641 (1977).

Puyallup Tribe v. Department of Game, Washington, 433 U.S. 165 (1977).

Oliphant v. Suquamish Tribe, 435 U.S. 191 (1978).

United States v. Wheeler, 435 U.S. 313 (1978).

Santa Clara Pueblo v. Martinez, 436 U.S. 49 (1978).

United States v. John, 437 U.S. 634 (1978).

Washington v. Confederated Bands of the Yakima Indian Nation, 439 U.S. 463 (1979).

Wilson v. Omaha Indian Tribe, 442 U.S. 653 (1979).

Washington et al. v. Washington State Commercial Passenger, 443 U.S. 658 (1979).

United States v. Clarke, 445 U.S. 253 (1980).

United States v. Mitchell, 445 U.S. 535 (1980).

Andrus v. Glover Construction Co., 446 U.S. 608 (1980).

Washington v. Confederated Tribes of the Colville Indian Reservation, 447 U.S. 134 (1980).

White Mountain Apache v. Bracker, 448 U.S. 136 (1980).

Central Machinery Co. v. Arizona State Tax Commission, 448 U.S. 160 (1980).

United States v. Sioux Nation of Indians, 448 U.S. 371 (1980).

Andrus v. Glover Construction Co., 448 U.S. 608 (1980).

Montana v. United States and Crow Tribe et al., 450 U.S. 544 (1981).

Merrion v. Jicarilla Apache Tribe, 455 U.S. 130 (1982).

Ramah Navajo School Board v. Bureau of Revenue, 458 U.S. 832 (1982).

Arizona v. California, 460 U.S. 605 (1983).

New Mexico v. Mescalero Apache Tribe, 462 U.S. 324 (1983).

Nevada v. United States, 463 U.S. 110 (1983).

United States v. Mitchell II, 463 U.S. 207 (1983).

Arizona v. San Carlos Apache Tribe, 463 U.S. 545 (1983).

Rice v. Rehner, 463 U.S. 713 (1983).

Solem v. Bartlett, 465 U.S. 463 (1984).

Escondido Mutual Water Co. v. La Jolla Band of Mission Indians, 466 U.S. 765 (1984).

Three Affiliated Tribes of the Fort Berthold Reservation v. Wold Engineering, 467 U.S. 138 (1984).

United States v. Dann, 470 U.S. 39 (1985).

County of Oneida v. Oneida Indian Nation, 470 U.S. 661 (1985).

Kerr-McGee Corporation v. Navajo Tribe, 471 U.S. 195 (1985).

Montana v. Blackfeet Tribe of Indians, 471 U.S. 749 (1985).

National Farmers Union Insurance v. Crow Tribe of Indians, 471 U.S. 845 (1985).

Mountain States Telephone and Telegraph v. Pueblo of Santa Ana, 472 U.S. 237 (1985). 
Oregon Department of Fish \& Wildlife v. Klamath Indian Tribe, 473 U.S. 753 (1985).

California State Board of Equalization v. Chemehuevi Indian Tribe, (1985).

United States v. Dion, 474 U.S. 734 (1986).

Bowen v. Roy, 476 U.S. 130 (1986).

South Carolina v. Catawba Tribe, 476 U.S. 498 (1986).

United States v. Mottaz, 476 U.S. 834 (1986).

Three Affiliated Tribes v. Wold Engineering, 476 U.S. 877 (1986).

Iowa Mutual Insurance Co. v. LaPlante, 480 U.S. 9 (1987).

California v. Cabazon Mission of Indians, 480 U.S. 202 (1987)

Amoco Production v. Gambell, 480 U.S. 531 (1987).

United States v. Cherokee Nation of Oklahoma, 480 U.S. 700 (1987).

Hodel v. Irving, 481 U.S. 704 (1987).

Lyng v. Northwest Indian Cemetery Protective Association, 485 U.S. 439 (1988).

Employment Division, Department of Human Resources of Oregon v. Smith, 485 U.S. 660 (1988).

Mississippi Band of Choctaw Indians v. Holyfield, 490 U.S. 30 (1989).

Cotton Petroleum v. New' Mexico, 490 U.S. 163 (1989).

Brendale v. Yakima Indian Nation, 492 U.S. 408 (1989).

Employment Division, Department of Human Resources v. Smith, 494 U.S. 874 (1990).

Duro v. Reina, 495 U.S. 676 (1990).

Oklahoma Tax Commission v. Potawatomi, 498 U.S. 505 (1991).

Blatchford v. Native Village of Noatak, 501 U.S. 775 (1991).

Negonsott v. Samuels, 507 U.S. 99 (1993).

Oklahoma Tax Commission v. Sac and Fox Nation, 508 U.S. 114 (1993).

Rhoades v. Vigil, 508 U.S. 182 (1993).

South Dakota v. Bourland, 508 U.S. 679 (1993).

* Cases listed include those decided in favor or against American Indian interests as well as split decisions. Per curiam decisions are also provided.

Acknowledgment: This is a revised version of a paper prepared for delivery at the 1994 annual meeting of the Midwest Political Science Association, Chicago, Illinois. The author would like to thank. Ming H. Lee, Karen O`Connor, and Thomas G. Walker for their invaluable comments. Special gratitude must also be extended to David A. Freeman and the three anonymous reviewers for their constructive criticism.

\section{NOTES}

1. Although American Indians are truly a disadvantaged minority in terms of a sense of powerlessness, numbers, racial or cultural characteristics, and a sense of group solidarity, their status as citizens in separate tribal nations gives them an unıque polıtical status that is different from that of other disadvantaged groups. Thus, the relationship between the United States and American Indians is also a political one.

2. See, generally Cherokee Nation v. State of Georgia (1831), United States v. Rickert (1903), Felix v. Patrick (1892), Elk v. Wilkins (1884), and Williams v. Lee (1959).

3. Per curiam decisions durıng this period were excluded. The author specifically chose not to use 
the Spaeth data base because the Spaeth data base operationalizes American Indian cases as those in which American Indians are a party. This study, in contrast, examıne all cases that had an influence on issues critical to American Indian interests, including those cases where the federal government is a party in aN case on behalf of American Indian interests.

4. Justices who served in less than five cases where American Indians were the appellant are excluded from this analysis, as it is difficult to reach meanıngful conclusions regarding their behavior.

\section{REFERENCES}

Baum, L. (1976). Decisions to Grant and Deny Hearings in the California Supreme Court: Patterns in Court and Individual Behavior. Santa Clara Law Review, 16: 713-744.

Baum. L. (1977). Policy Goals in Judicial Gatekeeping: A Proximity Model of Discretionary Jurisdiction. American Journal of Political Science, 21: 13-35.

Baum, L. (1979). "udicial Demand-Screening and Decisions on Merit: A Second Look. American Politics Quarterly, 7: 109-1 19.

Caplan, L. (1987). The Tenth Justice. New York: Knopf.

Cortner, R. (1968). Strategies and Tactics of Litigants in Constitutional Cases. Journal of Publıc Law, 17: 287-307.

Cohen. F. S. (1982). Felıx S. Cohen's Handbook of Indian Law. Charlottesville, VA: The Michie Company.

Deloria, V. and C. M. Lytle. (1983). American Indians, American Justice. Austin, TX: University of Texas Press.

Epstein, L. and K. O'Connor. (1988). States and the U.S Supreme Court: An Examination of Litigation Outcomes. Social Science Quarterlv, 69: 660-674.

Galanter, M. (1974). Why the 'Haves' Come Out Ahead: Speculations on the Limits of Legal Change. Law and Society Review, 9: 95-160.

George, T. E. and L. Epstein. (1992). On the Nature of Supreme Court Decision Making. American Political Science Review, 86: 323-337.

Goldman, S. (1982). Constitutional Law and Supreme Court Decision-Making. New York: Harper and Row.

Heck, E. V. (1981). Civil Liberties Voting Patterns in the Burger Court: 1975-1978. Western Political Quarterly, 34: 193-202.

Ivers, G. and J. Parker. (1993). The Solicitor General Gets Relıgion-Or Does He? Paper delivered at the 1993 Midwest Political Science Association. Palmer House. Chicago, Illinois, April $14-16$.

Johnson, R. W. (1990). 'In Simple Justice to a Downtrodden People': Justice Douglas and the American Indian Cases. In Stephen L. Wasby (Ed.), "He Shall Not Pass This Way Again": The Legacy of Justice William O. Douglas (pp. 191-213). Pittsburgh: University of Pittsburgh Press.

Lawrence, S. (1990). The Poor in Court: The Legal Services Programs and Supreme Court Decision Making. Princeton: Princeton Unıversity Press.

McGuire, K. T. (1993). The Supreme Court Bar: Legal Elites in the Washington Community. Charlottesville: University Press of Virginia.

O'Connor, K. (1980). Women's Organizations' Use of the Courts. Lexington, MA: Lexington University Press.

O'Connor, K. (1983). The Amicus Curiae Role of the U.S. Solıcitor General in Supreme Court Litigation. Judicature, 66: 256-264.

O'Connor. K. and L. Epstein. (1982). The Importance of Interest Group Involvement in Employment Discrimination Litigation. Howard Law Journal, 25: 709-728. 
O Connor, K. and L. Epstein. (1983). Sex and the Supreme Court: An Analysis of Judicial Support for Gender-Based Claims. Social Science Quarterly; 64: 327-331.

Perry, H. W. Jr. (1991). Deciding to Decide. Agenda Setting in the United States Supreme Court. Cambridge. MA: Harvard Unıversity Press.

Puro, S. (1971). The Role of the Amicus Curiae in the United States Supreme Court. Ph.D. dissertation. State University of New York at Buffalo.

Rohde. D. W. and H. J. Spaeth. (1976). Supreme Court Decision Making. San Francisco: Freeman.

Salokar, R. M. (1992). The Solicitor General: The Politics of Law. Philadelphia: Temple Unıversity Press.

Schwartz, B. (1993). A History of the Supreme Court. New York: Oxford University Press.

Scigliano, R. (1971). The Supreme Court and the Presidenci. New York: Free Press.

Segal. J. A. (1984). Predicting Supreme Court Cases Probablistically: The Search and Seizure Cases. American Political Sclence Review; 78: 891-900.

Segal. J. A. (1988). Amicus Curiac Briefs by the Solicitor General during the Warren and Burger Courts." Western Political Quarterli, 41. 135-144.

Segal, J. A. (1990). Supreme Court Support for the Solicitor General: The Effect of the Presıdential Appointments. Western Politıcal Quarterly; 4I: 137-152.

Segal, J. A. and C. D. Reedy. (1988). The Supreme Court and Sex Discrimination: The Role of the Solicitor General. Western Political Quarterly; 41: 553-568.

Segal, J. A. and H. J. Spaeth. (1993). The Supreme Court and the Attitudinal Model. New York: Cambridge University Press.

Shattuck, P. T. and J. Norgren. (1979). Political Use of the Legal Process by Black and American Indian Minorities. Howard Law Journal, 22: 1-26.

Shattuck, P. T. and J. Norgren. (1991). Partial Justice: Federal Indian Law in a Liberal Constitutional System. Providence: Berg.

Shechan, R. S., et. al. (1992). Ideology, Status, and the Differential Status of Direct Parties before the Supreme Court. American Political Science Review; 86: 464-474.

Songer, D. R. (1979). Concern for Policy Outputs as a Cue for Supreme Court Decisions on Certiorari. Journal of Politics, 41: 1185-1194.

Ulmer, S. S. and M. Thomson. (198I). Supreme Court Support for Black Litigants: A Comparison of the Warren and the Burger Courts. In S. S. Ulmer (Ed.). Courts, Law, and Judicial Processes (pp. 446-453). New York: Free Press.

Vose. C. E. (1959). Caucasians Only. Berkeley: University of California Press.

Wasby, S. L. (1993). The Supreme Court in the Federal Court System. Fourth Edition. New York: Nelson Hall.

Wilkins, D. E. (1990). The Legal Consciousness of the United States Supreme Court: A Critical Examination of Indian Supreme Court Decisions Regarding Congressional Plenary Power and Tribal Sovereignty - 1870-1921. Ph.D. Dissertation. Unıversity of North Carolina at Chapel Hill.

Wilkinson, C. F. (1987). American Indians, Time, and the Law: Natile Societies in a Modern Constitutional Democracy. New Haven: Yale University Press.

Wilkinson, C. F. (1990). Justice Douglas and the Public Lands. In S.L. Wasby (Ed.), "He Shall Not Pass This Way Again": The Legacy of Justice Willam O. Douglas (pp. 233-248). Pittsburgh: University of Pittsburgh Press.

Wunder, J. R. (1994). "Retained by The People:" A History of American Indıans and the Ball of Rights. New York: Oxford University Press. 